\title{
Author Correction: Maternal Sepsis: Recognition, Treatment, and Escalation of Care
}

\section{Emily E. Naoum ${ }^{1} \cdot$ Melissa E. Bauer ${ }^{1}$}

Published online: 16 January 2020

(C) Springer Science+Business Media, LLC, part of Springer Nature 2020

\section{Author Correction: Current Anesthesiology Reports (2019) 9(1):55-59.}

https://doi.org/10.1007/s40140-019-00310-7

The original version of this article contained two mistakes. In Table 2, under the "MEW criteria" heading, "DBP $<100$ mmHg" should read "DBP $>100 \mathrm{mmHg}$." The correct Table 2 is shown here.

The first sentence of the 3rd paragraph under "Antibiotics" section should read: "Early antibiotic therapy with broadspectrum antibiotics is critical on labor and delivery and requires a collaborative effort with other practitioners."
Table 2 Screening tools for maternal sepsis

SIRS criteria

Temperature $>38{ }^{\circ} \mathrm{C}$ or $<36{ }^{\circ} \mathrm{C}$

Respiratory rate $>20$ breaths per minute or $\mathrm{PaCO}_{2}<32 \mathrm{mmHg}$

Pulse $>90$ beats per minute

White blood cell count $>12,000$ cells $/ \mathrm{mm}^{3}$ or $<4000$ cells $/ \mathrm{mm}^{3}$, or bands $>10 \%$

qSOFA

Respiratory rate $>22$ breaths per minute

$\mathrm{SBP}<100 \mathrm{mmHg}$

Altered mental status

MEW criteria

$\mathrm{SBP}<90 *$ or $>160 \mathrm{mmHg}$

DBP $>100 \mathrm{mmHg}$

$\mathrm{HR}<50$ or $>120^{*}$

$\mathrm{RR}<10$ or $>30^{*}$

Oxygen saturation on room air at sea level $<95 \% *$

Oliguria $<35 \mathrm{~mL} / \mathrm{h}$ for $\geq 2 \mathrm{~h} *$

Maternal agitation, confusion, or unresponsiveness*

Patient with pre-eclampsia reporting a non-remitting headache or shortness of breath

*Parameters consistent with the physiology of sepsis
The online version of the original article can be found at https://doi.org/ 10.1007/s40140-019-00310-7

Melissa E. Bauer

mbalun@med.umich.edu

1 Department of Anesthesiology, University of Michigan, 1500 E Medical Center Drive, Ann Arbor, MI 48109, USA 